\title{
PENGARUH SKIN TO SKIN CONTACT (PMK) TERHADAP PENURUNAN SUHU TUBUH PADA BAYI DEMAM
}

\author{
Heni Purwaningsih ${ }^{1}$, Widuri $^{1}$ \\ ${ }^{1}$ Fakultas Keperawatan Universitas Ngudi Waluyo \\ bundobian@gmail.com
}

\begin{abstract}
Abstrak
Demam merupakan suatu keadaan suhu tubuh diatas normal sebagai akibat peningkatan pusat pengatur suhu di hipothalamus. Cara yang dapat menurunkan suhu tubuh adalah dengan menggunakan metode kontak kulit ibu dan kulit bayi (Skin to Skin Contact). Tujuan penelitian ini adalah untuk mengetahui pengaruh skin to skin contact (PMK) terhadap penurunan suhu tubuh pada bayi demam di Rumah Sakit Ken Saras Kabupaten Semarang. Jenis penelitian ini adalah Quasi Experimental dengan pre-post test dalam satu kelompok (One-Group Pre-test-posttest Design). Populasi adalah rata-rata jumlah bayi yang mengalami demam perbulan di Rumah Sakit Ken Saras selama tahun 2016 sebanyak 87 anak. Sampel 14 orang yang diambil secara purposive sampling. Alat pengumpulan data menggunakan termometer digital axila. Hasil penelitian menunjukkan terdapat perbedaan secara bermakna suhu tubuh pada bayi demam sesudah dilakukan skin to skin contact (PMK) dengan $p$ value $0,000<\alpha(0,05)$. Perawat dapat memberikan intervensi skin to skin contact (PMK) sebagai salah satu intervensi keperawatan nonfarmakologis dalam penatalaksanaan bayi demam.
\end{abstract}

Kata kunci: Bayi demam, skin to skin contact, perawatan metode kanguru

\begin{abstract}
The Effects of Skin to Skin Contact (PMK) on Body Temperature Decrease in Infants with Fever. Fever is a body temperature above normal circumstances as a result of increased temperature control center in the hypothalamus. One of the ways that can reduce body temperature is using skin to skin method of mother and baby's skin (Skin to Skin Contact). The purpose of this research is to analyze the effects of skin to skin contact (pmk) on body temperature decrease in infants with fever at Ken Saras Hospital of Semarang Regency. The type of this research was Quasi Experimental with pre-post test in one group (One-Group Pre-test-posttest Design). The population was all the average number of infants with fever per month at Ken Saras Hospital during 2017 as many as 38 patients. 14 samples were taken by purposive sampling. The collecting data tool used a axilla digital thermometer. The research results showed that there is a significant difference of body temperature in infants with fever after skin to skin contact (PMK) with $p$ value $0,000<\alpha(0,05)$. Nurses can provide skin to skin contact (PMK) interventions as one of the nonpharmacological nursing interventions in the management of infants with fever.
\end{abstract}

Keywords : Infants with fever, skin to skin contact, kangaroo care method

\section{Pendahuluan}

Demam merupakan suatu keadaan suhu tubuh diatas normal sebagai akibat peningkatan pusat pengatur suhu di hipothalamus (Sodikin, 2012). Salah satu penyebab deman pada bayi adalah infeksi bakteri dan paling sering ditemukan adalah infeksi saluran kemih (ISK). Bayi yang berusia dibawah 6 bulan beresiko paling besar mengalami pneumonia atau meningitis (infeksi selaput otak). Bayi $>3$ bulan dan bayi 1-3 tahun dengan demam > $39^{\circ} \mathrm{C}$, hanya $2 \%(1-3,6 \%)$ saja yang bakterinya sudah memasuki peredaran darah (bakteremia) (Guyton and Hall, 2012).

Kejadian demam dilaporkan sebagai salah satu Kejadian Ikutan Pasca Imunisasi (KIPI) campak dengan gejala demam lebih dari $39,5^{\circ} \mathrm{C}$ terjadi pada $5-15 \%$ kasus. Demam mulai dijumpai pada hari 5-6 sesudah imunisasi dan berlangsung selama 2 hari. Ruam juga dapat dijumpai pada 5\% resipien, timbul pada hari 7-10 sesudah imunisasi dan berlangsung selama 2-4 hari. KIPI dapat berupa timbulnya kemerahan, bengkak, dan nyeri pada lokasi penyuntikan. Selain itu, bayi akan menderita demam ringan, sering gelisah 
dan menangis terus menerus selama beberapa jam pasca suntikan (Profil Kesehatan Kota Semarang, 2009).

Badan Kesehatan Dunia (WHO) memperkirakan jumlah kasus demam di seluruh dunia mencapai $16-33$ juta dengan 500-600 ribu kematian tiap tahunnya (Proverawati dan Ismawati, 2011). Data kunjungan ke fasilitas kesehatan pediatric di Brazil terdapat sekitar 19\% sampai 30\% anak diperiksa karena menderita demam. Penelitian oleh Ahmed et al.,(2017) di Kuwait menunjukkan sebagian besar anak usia 3-36 bulan mengalami serangan demam rata-rata 6 kali pertahunnya. Di Indonesia penderita demam sebanyak 465 dari 511 ibu yang memakai perabaan untuk menilai demam pada anak mereka sedangkan sisanya 23,1 saja yang menggunakan termometer (Deswita, Besral, 2011). Data yang didapatkan dari Ruang Diamond Rumah Sakit Ken Saras Kabupaten Semarang pada bulan Januari 2017 hingga Desember 2017 terdapat 165 pasien anak yang masuk rumah sakit dengan gejala demam. Penyakit terbanyak dengan gejala demam yaitu Ispa, bronkopneumonia, demam typhoid, gastroenteritis, dan Dengue Haemoragic Fever (RS Ken Saras Kabupaten Semarang, 2017).

Demam pada anak dibutuhkan perlakuan dan penanganan tersendiri yang berbeda bila dibandingkan dengan orang dewasa. Demam dapat membahayakan keselamatan pasien jika tidak ditangani dengan cepat dan tepat akan menimbulkan komplikasi lain seperti hipertermi, kejang, dan penurunan kesadaran (Maharani, 2011). Bayi yang mengalami demam, untuk menurunkan suhu tubuhnya dapat dilakukan dengan berbagai cara antara lain manajemen cairan, kompres, manajemen lingkungan dan pemberian antipiretik.

Cara lain yang dapat menurunkan suhu tubuh adalah dengan menggunakan metode kontak kulit ibu dan kulit bayi (Skin to Skin Contact). Metode ini merupakan bentuk interaksi antara orangtua dengan bayinya yang lebih dikenal dengan perawatan metode Kanguru. Penelitian yang dilakukan (Lawn et al., 2010) menyatakan skin to skin contact efektif untuk menumbuhkan efek positif pada ikatan kasih sayang antara ibu dan bayi. Skin to skin contact dapat menimbulkan dampak positif yang signifikan pada bayi dan mempengaruhi hubungan orang tua bayi dalam berinteraksi (Mardi asih, Sri hartini, Wanda Dessie, 2013)

Berdasarkan hasil riset mengenai skin to skin contact, bahwa terdapat manfaat dari teknik ini baik dari fisiologis maupun dari perilaku bayi dengan berat badan lahir rendah. Metode ini terbukti dapat memperbaiki status metabolisme bayi, regulasi termal, pola nafas dan saturasi oksigen, mengurangi apnea dan bradikardi, meningkatkan angka berat badan dan produksi ASI, memperpendek hari rawat, dan berfungsi sebagai analgesik selama prosedur medis yang menyebabkan nyeri. Penelitian yang dilakukan Lawn et al (2010) menunjukkan bahwa Skin to skin contact meningkatkan suhu tubuh ke arah normal pada bayi berat lahir rendah serta meningkatkan denyut jantung dan kenaikan oksigen.

\section{Metode}

Desain penelitian ini adalah Quasi Experimental dengan pre-post test dalam satu kelompok (One-Group Pre-testposttest Design). Populasi dan Sampel dalam penelitian ini adalah bayi yang menjalani rawat inap di Rumah Sakit Ken Saras Kabupaten Semarang yang mengalami demam sejumlah 14 bayi pada bulan Januari-Februari 2018. Alat penggumpulan data berupa termometer digital axila dan Standar Operasional Prosedur (SOP) Skin to Skin Contact. Analisis data menggunakan t-test independent.

\section{Hasil}

Adapun hasil penelitian dapat dilihat pada table berikut: 
Penelitian yang dilakukan Ahmed et al (2017) mengatakan bahwa sebagian besar bayi berusia 3 bulan sampai dengan 36 bulan mengalami demam rata-rata 6 kali pertahun. Bayi berumur kurang dari 2 bulan lebih sering menunjukkan demam minimal atau tidak demam sama sekali pada saat menderita infeksi. Bayi sebagian besar mengalami demam sebagai respon terhadap infeksi virus yang bersifat self limited dan berlangsung tidak lebih dari 3 hari. Hasil penelitian tersebut mempunyai asumsi bahwa usia dimungkinkan dapat mempengaruhi penurunan suhu tubuh sehingga tujuan pembatasan usia pada penelitian ini adalah untuk mengurangi bias penelitian yang disebabkan oleh karakteristik yang tidak sama.

Hasil penelitian menunjukkan bahwa semua bayi yang dirawat ditunggui oleh ibunya. Penelitian ini sesuai dengan yang dilakukan oleh (Lawn et al., 2010) bahwa faktor pendukung utama bayi sakit adalah ibu. Pengetahuan dan kecemasan ibu mempengaruhi kemampuan penatalaksanaan demam yang akan diterima oleh bayi. Suhu tubuh adalah perbedaan antara jumlah panas yang diproduksi oleh tubuh dan jumlah panas yang hilang ke lingkungan luar (Potter dan Perry, 2009). Pengaturan suhu dikendalikan oleh mekanisme keseimbangan antara pembentukan panas dan kehilangan panas (Sherwood, 2011). Hal ini menunjukan bahwa suhu masingmasing responden bervariasi.

Suhu tubuh diatur oleh hipotalamus yang terletak di antara dua hemisfer otak. Fungsi hipotalamus adalah seperti termostat, suhu yang nyaman merupakan set-point untuk operasi sistem pemanas. Hipotalamus mendeteksi perubahan kecil pada suhu tubuh. Hipotalamus anterior mengatur kehilangan panas, sedangkan hipotalamus posterior mengatur produksi panas. Jika sel saraf di hipotalamus anterior menjadi panas di luar batas titik pengaturan (set point), maka impuls dikirimkan untuk menurunkan suhu tubuh (Potter dan Perry, 2009).

\section{Gambaran Suhu Tubuh Sesudah Dilakukan Skin to Skin Contact (PMK) pada Bayi Demam}

Hasil penelitian menunjukkan bahwa rata-rata suhu tubuh pada bayi demam sesudah dilakukan skin to skin contact (PMK) sebesar $37,6^{\circ} \mathrm{C}$ dengan suhu tubuh tertinggi $38,6^{\circ} \mathrm{C}$ dan suhu tubuh terendah $36,8^{0} \mathrm{C}$. Salah satu manfaat dari skin to skin contact (PMK) adalah dapat memperbaiki status metabolisme bayi dan regulasi termal. Skin to skin contact (PMK) dapat menurunkan suhu tubuh bayi yang sedang demam adalah berdasarkan mekanisme perpindahan panas yang terjadi dari suhu tubuh ibu ke bayi yang sedang mengalami hipotermi.Sebaliknya bayi yang hipertermi juga dapat memindahkan suhu tubuhnya ke ibu melalui proses konduksi (Deswita, Besral, 2011).

Pengeluaran panas secara normal melalui radiasi, konduksi, konveksi, dan evaporasi (Potter dan Perry, 2009). Radiasi adalah perpindahan panas dari permukaan satu objek kepermukaan objek lain, tanpa keduanya bersentuhan. Konduksi adalah perpindahan panas dari satu objek ke objek lain dengan kontak langsung. Konveksi adalah penyebaran panas melalui gerakan udara. Kipas angin listrik meningkatkan kehilangan panas melalui konveksi. Evaporasi adalah perpindahan energi panas ketika cairan berubah menjadi gas. Selama evaporasi kira kira 0,6 kalori panas hilang untuk setiap gram air yang menguap (Guyton \& Hall, 2011).

Pada penelitian ini perpindahan panas adalah dengan tehnik konduksi, dimana perpindahan panas dari tubuh bayi ke tubuh ibu sehingga dapat menurunkan suhu tubuh bayi. Ikatan emosional yang disebut bonding atau attachment merupakan suatu proses hubungan bayi dengan orangtuanya. Kebutuhan bayi terhadap orangtua bersifar absolute, tetapi kebutuhan orangtua terhadap bayi bersifat relatif. Hal ini dikuatkan dalam penelitian yang dilakukan Sodikin (2012) yang menyatakan bahwa skin to skin contact (PMK) efektif untuk menumbuhkan efek 
positif pada ikatan kasih sayang antara ibu dan bayi.

Hasil tersebut didukung oleh teori yang dikemukakan oleh Depkes RI (2014) bahwa ibu yang melakukan skin to skin contact (PMK) merasa lebih percaya diri dalam merawat bayinya dibandingkan dengan ibu yang tidak melakukan perawatan metode kanguru. Skin to skin contact (PMK) juga meningkatkan kedekatan ibu dengan bayinya, mengurangi perasaan stress pada ibu sebagaimana halnya pada bayi, serta membuat ibu dan bayi, serta membuat ibu dan bayi lebih tenang dan rileks. Faktor pendukung pada penelitian ini adalah kebanyakan bayi diasuh oleh ibunya, hal ini menunjukkan bahwa hubungan ibu dan bayi menstabilkan suhu tubuh bayi.

\section{Pengaruh Skin to Skin Contact (PMK) terhadap Penurunan Suhu Tubuh pada Bayi Demam}

Hasil penelitian menunjukkan bahwa terdapat penurunan suhu tubuh pada bayi demam sesudah dilakukan skin to skin contact (PMK) dengan rata-rata penurunan suhu tubuh sebesar $0,5071^{\circ} \mathrm{C}$. Hal ini membuktikan bahwa metode skin to skin contact (PMK) mempunyai manfaat untuk mengurangi suhu tubuh pada bayi demam. Hasil penelitian ini juga didukung oleh pendapat Proverawati dan Ismawati (2011) bahwa dengan skin to skin contact (PMK) maka bayi akan lebih merasa nyaman karena dapat mendengar detak jantung ibunya yang pada akhirnya metode skin to skin contact (PMK) ini lebih cepat dalam menstabilkan suhu tubuh bayi. Keuntungan dan manfaat skin to skin contact (PMK) yang lainnya adalah mempercepat pengeluaran Air Susu Ibu (ASI) dan meningkatkan keberhasilan menyusui, perlindungan bayi dari infeksi serta memberikan stimulasi dini.

Teori yang mendukung hasil penelitian ini adalah yang diungkapkan oleh Soni et al., (2017) bahwa perawatan metode kanguru efektif dalam mengontrol suhu tubuh bayi. Termoregulasi merupakan salah satu tugas yang paling berat saat bayi baru lahir beradaptasi pada lingkungan ekstra uterin. Suhu tubuh bayi menjadi menurun ketika ia menyusu pada ibunya dengan menggunakan metode skin to skin contact (PMK).

Dengan uji t-test dependent diperoleh angka signifikansi (nilai $\mathrm{p}$ ) = 0,000 dimana $\alpha(0,05)$. Sehingga dapat disimpulkan bahwa terdapat perbedaan secara bermakna suhu tubuh pada bayi demam sesudah dilakukan skin to skin contact (PMK) dengan $p$ value $0,000<\alpha$ $(0,05)$. Analisis tersebut menunjukkan bahwa skin to skin contact (PMK) merupakan alternatif pengganti inkubator, adapun kelebihannya antara lain merupakan cara yang efektif untuk memenuhi kebutuhan bayi yang paling mendasar yaitu adanya kontak kulit bayi ke kulit ibu, dimana tubuh ibu akan menjadi termoregulator bagi bayi (Soni et al., 2017) Berdasarkan hasil penelitian dapat teridentifikasi beberapa penyebab peningkatan suhu tubuh bayi yaitu karena ISPA, ISK, gastroenteritis dan bronkopneumonia. Penyebab-penyebab tersebut tergolong dalam penyebab demam karena infeksi. Data ini didapatkan pada lembar kuesioner yang tertera pada item diagnosa penyakit/ medis. Hasil penelitian ini dapat dikatakan bahwa skin to skin contact (PMK) dapat menurunkan suhu tubuh bayi yang mengalami demam karena infeksi ringan. Bayi setelah dilakukan skin to skin contact (PMK) akan terjadi penurunan set point pada pusat pengatur suhu, keadaan ini membuat aliran darah ke kulit meningkat sehingga bayi tersebut akan merasa kepanasan dan mengeluarkan keringat banyak (Sherwood, 2011).

\section{Simpulan dan Saran}

Rata-rata suhu tubuh pada bayi demam sebelum dilakukan skin to skin contact (PMK) sebesar $38,1^{\circ} \mathrm{C}$ dengan suhu tubuh tertinggi $38,6^{\circ} \mathrm{C}$ dan suhu tubuh terendah $37,6^{\circ} \mathrm{C}$. Rata-rata suhu tubuh pada bayi demam sesudah dilakukan skin to skin contact (PMK) sebesar $37,621^{\circ} \mathrm{C}$ dengan 
suhu tubuh tertinggi $38,6^{\circ} \mathrm{C}$ dan suhu tubuh terendah $36,8^{\circ} \mathrm{C}$. Terdapat penurunan suhu tubuh pada bayi demam sesudah dilakukan skin to skin contact (PMK) dengan ratarata penurunan suhu tubuh sebesar $0,5071^{\circ} \mathrm{C}$. Sehingga dapat disimpulkan bahwa terdapat perbedaan secara bermakna suhu tubuh pada bayi demam sesudah dilakukan skin to skin contact (PMK) dengan $p$ value $0,000<\alpha(0,05)$. Diharapkan perawat dapat memberikan intervensi skin to skin contact (PMK) sebagai salah satu intervensi keperawatan non farmakologis dalam penatalaksanaan bayi demam.

\section{Daftar Pustaka}

Ahmed, N. et al. (2017) 'Kuwaiti parent' s knowledge of their children' $\mathrm{s}$ fever and their patterns of use of over the counter antipyretics What this study adds ':, 10(10), pp. 848855.

Depkes RI. (2008). Perawatan Bayi Berat Lahir Rendah (BBLR) dengan Metode Kanguru. Jakarta:Health Technology Assessment Indonesia. Depkes RI.

Deswita, Besral, R. Y. (2011) 'Pengaruh Perawatan Metode Kanguru terhadap Respons Fisiologis Bayi Prematur The Influence of Kangaroo Mother Care on Physiological Response of Premature Infants', Jurnal Kesehatan Masyarakat Nasional, 5(156), pp. 227-233. doi: DOI: http://dx.doi.org/10.21109/kesmas. v5i5.131 ...

Dinkes Kota Semarang. (2009). Profil Kesehatan Kota Semarang. Semarang: Dinkes Kota Semarang.

Guyton \& Hall. (2011). Buku Ajar Fisiologi Kedokteran. Edisi 9. Jakarta: EGC.
Lawn, J. E. et al. (2010) “" Kangaroo mother care " to prevent neonatal deaths due to preterm birth complications', 39(I), pp. 144-154. doi: 10.1093/ije/dyq031.

Maharani. (2011). Mengenali dan Memahami Berbagai Gangguan Kesehatan Anak . Jogjakarta: Katahati.

Mardi asih Sri hartini, Wanda Dessie, R. Y. (2013) '329-682-1-SM.pdf', jurnal Keperawatan dan Kebidanan (JIKK). Semarang: Junal Keperawatan dan Kebidanan (JIKK), I(9), pp. 505-515. Available at: http://ejournal.stikestelogorejo.ac.id /index.php/jikk/article/view/329.

Potter Perry(2009). Fundamental of Nursing, Buku 1, Edisi : 7. Jakarta: Salemba Medika.

Proverawati dan Ismawati. (2010). Berat Badan Lahir Rendah. Yogyakarta: Nuha Medika.

Sherwood, L. (2011). Fisiologi Manusia dari Sel ke Sistem Edisi 2. Jakarta: EGC.

Sodikin. (2012). Prinsip Perawatan Demam Pada Anak. Yogyakarta: Pustaka Pelajar.

Soni, A. et al. (2017) 'HHS Public Access', 105(9), pp. 1-13. doi: 10.1111/apa.13445.The.

Sherwood, L. (2011). Fisiologi Manusia dari Sel ke Sistem Edisi 2. Jakarta: EGC.

Sodikin. (2012). Prinsip Perawatan Demam Pada Anak. Yogyakarta: Pustaka Pelajar. 